\title{
Leverage Change, Share Repurchases, and Capital Expenditures
}

\author{
Bishal BC \\ Grand Valley State University \\ Yatin N. Bhagwat \\ Grand Valley State University \\ Marinus DeBruine \\ Grand Valley State University
}

Critics of share repurchases maintain that firms forego capital expenditures to boost their share price short-term while other researchers provide evidence that some repurchasing firms concurrently increase capital expenditures. Using a matched sample approach, this study examines the repurchasing and investing behavior of 17,466 firm-year observations for the period 2000 through 2019. We find that the financing of share repurchases affects the level of concurrent investments; that is, compared to cashfinanced repurchasing firms, debt-financed repurchasing firms increase concurrent capital expenditures. This finding is not as surprising as it seems as firms that take on more debt reduce their weighted average cost of capital, which allows managers to increase capital expenditures, as projects that were previously Net Present Value (NPV) negative may now become NPV positive. We follow this up by examining the interaction between a change in leverage and concurrent capital expenditures and find support for that notion. We also find that this is especially the case with firms that are not already heavily leveraged.

Keywords: leverage change, share repurchases, capital expenditures

\section{INTRODUCTION}

It could read as a tale of two boardrooms - the places where firms decide on their strategic outcomes and their transactions with shareholders, and where maximizing shareholder value is among the reigning principles. The late nineties and beyond promised an exciting growth period for computer software/hardware companies. IBM and Microsoft participated in this rush with slightly different approaches and very different growth outcomes from 1996 through 2014. Of course, we were not present at any board meetings, but we do have access to financial reports to help reconstruct this tale. Microsoft generated the highest cash flow from operations (32\% of total assets) and used that to repurchase shares during 15 of 19 years, while it also grew the fastest by acquiring other companies. During the few years that Microsoft's cash flow from operations was down (26\% of total assets), it used debt to repurchase shares. IBM trailed Microsoft in generating cash flow from operations (14.5\% of total assets) during those same 19 years and primarily used those cash flows for growing its existing businesses while it used debt to finance its share repurchases during 16 of those 19 years. 
Although the preceding paragraph shows their differences during those 19 years, there is an important similarity: both companies show higher levels of capital expenditures during the years when they finance their share repurchases. What's more, another competitor - Hewlett Packard - acted similarly during those 19 years: in years when it financed its share repurchases, it showed higher capital investment levels (as compared to the 12 years when it distributed its excess cash). Table 1 shows the average repurchases, average net borrowings, and the average capital expenditures for those three companies. To enhance comparability across time and firms, all amounts used to calculate those averages have been first standardized by average beginning total assets. Debt-financed repurchase years are defined as years when net borrowings equal or exceed $50 \%$ of the share repurchases for that year.

\section{TABLE 1}

\section{CASH- AND DEBT-FINANCED SHARE REPURCHASE ACTIVITIES BY TECHNOLOGY FIRMS}

\begin{tabular}{lccccc}
\hline Company & $\begin{array}{c}\text { Share repurchases } \\
\text { financed with }\end{array}$ & $\begin{array}{c}\text { Years } \\
\text { Debt }\end{array}$ & $\begin{array}{c}\text { Average share } \\
\text { repurchases }\end{array}$ & $\begin{array}{c}\text { Average net } \\
\text { borrowings }\end{array}$ & $\begin{array}{c}\text { Average capital } \\
\text { investments }\end{array}$ \\
IBM & 16 & 0.090 & 0.094 & 0.050 \\
Microsoft & Cash & 3 & 0.049 & 0.018 & 0.043 \\
& Debt & 4 & 0.090 & 0.064 & 0.036 \\
Hewlett-Packard & Cash & 15 & 0.161 & 0.004 & 0.029 \\
& Debt & 7 & 0.040 & 0.059 & 0.054 \\
& Cash & 12 & 0.073 & 0.021 & 0.036 \\
\hline \hline
\end{tabular}

This table presents share repurchases and other information on three technology firms from 1996-2014.

Not surprisingly, Table 1 shows that all three companies had significantly higher net borrowings for the debt-financed years than for years with cash-financed repurchases. However, what is surprising is that those three firms also reported higher capital expenditures in those years of higher net borrowings.

During the previous decade it has become popular for firms to repurchase share by issuing debt. This decision is less controversial than using operating cash for share repurchases because the cash paid out to shareholders is raised from debtholders. This in turn has a favorable impact on the firm's weighted average cost of capital, and an added benefit is that firms save taxes because the interest payments are tax deductible while money borrowed will have to be paid back in future years. We believe this is no coincidence but rather the result of a strategic decision to lower the cost of operating capital, which allows managers to increase capital expenditures, as projects that were previously Net Present Value (NPV) negative may now become NPV positive.

Share repurchases have overtaken dividends as the preferred form of capital distribution in virtually every year since the early 1990s (Fama and French, 2001; Dittmar and Dittmar, 2008). This development has generated controversy and firms have been accused of foregoing capital expenditures in their future (Lazonick, 2014; Lazonick et al., 2020). On the other hand, Milano and Chew (2019) point out that share repurchases play a critical role by recycling excess capital from large, mature companies with fewer growth opportunities to the next generation of Apples and Amazons. Earlier studies support the criticism that repurchasing firms decrease corporate spending and capital projects. Grullon and Michaely (2004) and Lei (2005) find that companies make trade-offs between share repurchases and capital expenditures and attribute it to a decrease in growth opportunities. Hribar et al. (2006) and Almeida et al. (2016) show that repurchasing firms motivated by earnings management decrease their investment in capital expenditures, employment levels, and research and development. More recently, BC et al. (2019) find that in years when firms increase their capital expenditures, repurchasing firms increase their capital expenditures more than their non-repurchasing counterparts, consistent with the excess cash flow hypothesis (Jensen, 1986). Conversely, in years when firms decrease their capital expenditures, BC et al. (2019) find that repurchasing firms decrease their capital expenditures more than their non-repurchasing counterparts, consistent with the signaling undervalued equity hypothesis (Tsetsekos et al., 1991; Ikenberry et al., 1995). This paper adds to 
this line of research by examining the impact of a firm's financing decisions - share repurchases and debt issuances - on the firm's concurrent capital expenditures decision.

Motivated by our earlier observations, this paper investigates the relationship between the share repurchasing firms' financing and investment decisions. Using observed investing decisions surrounding share repurchase decisions for a balanced panel of 17,466 firm-year observations from that same period, this paper investigates how the share repurchase financing decision affects capital investment decisions. As has become customary in this line of research, propensity score matching is used to match our sample on industry affiliation, firm size, and prior-year changes in capital expenditures. We find that - as compared to cash-financed repurchase firms - debt-financed repurchasing firms increase their concurrent capital expenditures. This preliminary result is at odds with the Lei \& Zhang (2016) finding that debt-financed share repurchases lead to lower capital expenditures which they attribute to lower growth opportunities for those firms. Instead, we suspect that firms choose debt-financed share buybacks to increase their leverage and decrease their weighted average cost of capital, which allows managers to increase capital expenditures, as projects that were previously NPV negative may now become NPV positive.

Encouraged by those preliminary results, we expand on our intuition that an increase in leverage is associated with a concurrent increase in capital expenditures. We first explore the mathematical relationship between leverage and the weighted average cost of capital and follow that up with arguments that the cost of capital affects the number of NPV positive projects available to the firm. We then test our hypotheses on the full set of 74,906 firm-year observations from the years 2000 through 2019 . We find that the change in leverage is positively related to the change in capital expenditures. Consistent with prior studies, we find that the level of leverage is negatively related to the change in future capital expenditures.

Our paper contributes to the literature on share repurchases. This literature suggests that firms repurchase shares to distribute excess cash (Dittmar, 2000) when they lack future growth opportunities (Grullon and Michaely, 2004; Lei, 2005), to manage earnings per share (Hribar et al., 2006; Almeida, 2016), and to signal undervalued equity (Ikenberry et al., 1995; Peyer and Vermaelen, 2007; BC et al., 2019). This paper contributes to this literature by showing that the source of financing for these repurchases matters in that firms that use debt for refinancing seems to make more capital investments than their peers who use cash.

Our paper also relates to the literature that studies the effects of leverage on capital expenditures. Prior studies have established that capital expenditures are negatively related to the level of leverage (Lang et al., 1996; Dang, 2011; Kahle and Stulz, 2013) and the lagged change in leverage (Hu, 1999; Cai and Zhang, 2011). This is the first paper to investigate the concurrent relationship between the change in leverage and change in capital expenditures to the best of our knowledge. In that regard, this paper contributes to this line of literature by providing support for the position that an increase in leverage increases concurrent capital expenditures.

The rest of this paper is organized as follows: Section 2 provides the literature review and develops a theoretical framework with hypotheses; Section 3 describes the methodology and sample selection; Section 4 presents the results and discusses the findings, and Section 5 concludes.

\section{LITERATURE REVIEW AND HYPOTHESES}

\section{Share Repurchases and Capital Expenditures}

Since before the start of this century, share repurchases have outstripped dividends and become the preferred way for distributing a firm's assets to owners (Skinner, 2008). In the early years, it may have been because of the popularity of stock options, but since the beginning of this century, the popularity of share repurchases has been attributed to tax advantages and flexibility (Kahle, 2002; Brav et al., 2005; Floyd et al., 2015). Dittmar (2000) shows that firms repurchase shares for many reasons, including distributing excess cash, signaling undervaluation, accommodating stock option plans, and recalibrating financial leverage. These actions are often interpreted as ways to increase shareholder wealth.

Not everyone is convinced that share repurchases increase shareholder wealth. Lazonick (2014) argues that share repurchases come at the expense of capital expenditures. Dittmar and Field (2015) show that 
management repurchases share when prices are high, thus ostensibly harming the firm's remaining shareholders. Hribar et al. (2006) argue, and Almeida et al. (2016) show that firms may repurchase shares to boost their EPS while shaving capital expenditures in the process. Most recently, Lazonick et al. (2020) - referring to the trillions of dollars that major firms have spent on share repurchases over this period and $\$ 800$ billion in 2018 alone - argue that firms deprive themselves of the liquidity that could help them cope when sales and profits decline in an economic downturn.

The relationship between share repurchases and capital expenditures has been investigated for many years. Jensen (1986) argues that excess cash presents a problem when managers have incentives to invest in value-destroying projects. By returning excess cash to shareholders, share repurchases should mitigate this problem. Grullon \& Michaely (2004), Richardson (2006), and Bhagwat and DeBruine (2018) provide evidence to suggest that share repurchases mitigate the potential over-investment problem. Using a large sample from 1998 through 2014 matched on industry affiliation, fiscal year, size, and growth opportunities, Bhagwat and DeBruine (2018) find that repurchasing firms and their non-repurchasing counterparts make similar investments in capital expenditures and research and development. In a subsequent study, BC et al. (2019) find that the results in Bhagwat and DeBruine (2018) - where the authors find no difference in the level of or change in capital expenditures between share repurchasing firms and non-repurchasing firms - may be driven by two opposing forces. Using the direction of capital expenditures as an indication of the firms' private information on growth prospects they find that - consistent with the excess cash hypothesis -repurchasing firms facing declining growth prospects are more likely to over-invest than their nonrepurchasing counterparts, while - consistent with the signaling hypothesis - repurchasing firms facing improving growth prospects are more likely to under-invest than their non-repurchasing counterparts yielding no net difference between repurchasing and non-repurchasing firms. These studies focused on the motivation for share repurchases while taking the motivation for capital expenditures for granted.

For a firm to incur capital expenditures, it needs a pool of NPV positive projects, which is affected by the firm's weighted average cost of capital. Ceteris paribus, the lower the weighted average cost of capital, the larger the pool of NPV positive projects. In a study of 2,759 open market repurchase announcements from 1980 to 1997, Grullon and Michaely (2004) argue that share repurchases lower a repurchasing firm's cost of capital. Using a market model as well as the Fama and French (1993) three-factor model, they find that the average cost of capital declines significantly - by 1.43 percent and 0.9 percent, respectively - for repurchasing firms which brings their initially higher cost of capital closer to that of their non-repurchasing counterparts. We expect that this, in turn, increased the pool of NPV positive projects available to those firms. In that same vein, we expect that debt-financed repurchasing firms lower their cost of capital even further than cash-financed repurchasing firms, thereby increasing the pool of NPV positive projects even further.

Other researchers have made leverage the focus of their investigation in value-increasing motives for share repurchases. Early on, Dittmar (2000) finds that firms repurchase stock during certain periods to alter their leverage ratio. Focusing on non-defensive self-tender offers, Lie (2002) finds that repurchasing firms have declining debt ratios before those offers while the post-event debt ratios are, on average, similar to predicted debt ratios. Bonaimé et al. (2014) and Lei and Zhang (2016) document that leverage adjustments obtained by share repurchases create a positive stock price reaction. The latter paper also investigates the impact of leveraged share repurchases on capital expenditures. Using a sample of 218 debt-financed and 357 cash-financed repurchases from 1994 through 2012, they find that debt-financed repurchase firms reduce capital expenditures more drastically - ex-post - than cash-financed repurchase firms. Upon further investigation, they attribute this finding to the debt-financed repurchasing firms' lower growth prospects in their sample.

The notion that debt-financed repurchasing firms face fewer growth opportunities does not agree with our observation of the three technology companies' behavior nor with our understanding of the literature. Going back more than thirty years, Jensen (1986) showed that to avoid overinvestments firms should distribute excess cash to maximize shareholder value, where "excess" implied that such firms did not have access to a sufficiently high number of positive NPV projects. Cash-based repurchases (as well as cash dividends) are the most direct tool for accomplishing this objective. On the other hand, debt-financed 
repurchases do not distribute excess cash; instead, those firms preserve their available cash for capital expenditures or other purposes. Based on our earlier observation of the three technology companies' behavior and the earlier-discussed finding in Grullon and Michaely (2004), we expect that debt-financed repurchasing firms spend more on capital expenditures than their cash-financed repurchasing counterparts because debt-financed repurchasing firms increase their leverage (and thus lower their cost of capital) more than cash-financed repurchasing firms. This leads to our first hypothesis:

H1: As compared to cash-financed repurchases, debt-financed repurchases are associated with a higher increase in concurrent capital expenditures.

Debt inherently increases the risk profile of firms. Several studies (e.g., Lang et al., 1996; Marchica and Mura, 2010; Cai and Zhang, 2011; Dang, 2011) have shown that (beginning) leverage is negatively related to future capital investments. We argue that firms with higher leverage will face a higher cost of debt that negatively impacts the cost of capital and a firm's available pool of positive NPV projects. This leads to our second hypothesis:

H2: As compared to cash-financed repurchases, debt-financed repurchasing firms with higher leverage have lower increases in capital expenditures.

Debt-financed repurchasing firms represent a subset of the firms increasing their debt and - at the same time and more importantly - increasing their leverage. We now turn to the relationship between debt, leverage, and capital expenditures.

\section{Leverage and Capital Expenditures}

Financial statement analysis textbooks agree on the following relationships between the cost of operating capital $\left(\mathrm{R}^{\mathrm{a}}\right)$, the (after-tax) cost of debt capital $\left(\mathrm{R}_{\mathrm{d}}\right)$, and the cost of equity capital $\left(\mathrm{R}_{\mathrm{e}}\right)$ :

$R_{a} \cdot V^{A}=R_{d} \cdot V^{D}+R_{e} \cdot V^{E}$

where $\mathrm{V}^{\mathrm{A}}, \mathrm{V}^{\mathrm{D}}$, and $\mathrm{V}^{\mathrm{E}}$ represent - respectively - the market values of the firm's (net) operating assets, its (net) debt, and its common stock. Rearranging terms in Equation (1), those textbooks then express the cost of operating capital $\left(\mathrm{R}_{\mathrm{a}}\right)$ - hereafter called the weighted average cost of capital (WACC) - as a function of all other variables in Equation (1), as follows:

$\mathrm{R}_{\mathrm{a}}=\mathrm{WACC}=\mathrm{R}_{\mathrm{d}} \cdot \mathrm{V}^{\mathrm{D}} / \mathrm{V}^{\mathrm{A}}+\mathrm{R}_{\mathrm{e}} \cdot \mathrm{V}^{\mathrm{E}} / \mathrm{V}^{\mathrm{A}}$

Equation (2) is used extensively in those textbooks to illustrate how a shift in the firm's leverage affects the weighted average cost of capital. It typically goes something like this: A firm's enterprise value is $\$ 100$ million while the market value of its common equity is $\$ 60$ million. The after-tax cost of debt $\left(\mathrm{R}_{\mathrm{d}}\right)$ is $4 \%$, while the cost of equity capital is $12 \%$. What is this firm's weighted average cost of capital and how will it change after the firm issues $\$ 20$ million in additional debt? Using Equation (2), the standard solution is that the weighted average cost of capital decreases. Before issuing the additional debt, the weighted average cost of capital is:

$\mathrm{WACC}=(.04) \cdot 40 / 100+(.12) \cdot 60 / 100=.016+.072=.088$ or $8.8 \%$

Then the \$20 million in additional debt increases total assets and lowers the weighted average cost of capital as follows:

$\mathrm{WACC}=(.04) \cdot 60 / 120+(.12) \cdot 60 / 120=.020+.060=.080$ or $8.0 \%$ 
There is typically some reference made that taking on more debt could marginally affect the interest rate charged on the new debt, which would slightly increase $R_{d}$ in Equation (2). However, this depends on several other factors, including the general interest rates at the time, so this is mostly ignored. As a result, the weighted average cost of capital is brought down by taking on debt, which increases the firm's pool of positive NPV projects - in this case all those projects with an internal rate of return between $8.0 \%$ and $8.8 \%$. Of course, this firm could lower its weighted average cost of capital still further by using part of the debt funding for repurchasing shares. For example, assume the firm decides to repurchase $\$ 12$ million of its common shares. This would reduce its enterprise value from $\$ 120$ million to $\$ 108$ million and leave just $\$ 8$ million of the debt funding for other purposes. As a result of this repurchase, its weighted average cost of capital would reduce as follows:

$\mathrm{WACC}=(.04) \cdot 60 / 108+(.12) \cdot(60-12) / 108=.022+.053=.075$ or $7.5 \%$

A thus lowered WACC should increase this firm's pool of NPV positive projects still further. In a study of open market share repurchase announcements over the period 1980 to 1997, Grullon and Michaely (2004) use a market model as well as the Fama and French (1993) three-factor model to show that the cost of capital of repurchasing firms moves toward the lower cost of capital of their non-repurchasing counterparts. This leads to our third hypothesis:

\section{H3: A change in leverage is positively associated with a change in the concurrent capital expenditures.}

\section{High-Leverage Firms and Capital Expenditures}

Similar to $\mathrm{H} 2$ that focused on debt-financed repurchasing firms, we expect that firms with higher leverage will face a higher cost of debt that negatively impacts the weighted average cost of capital and a firm's pool of positive NPV projects. Analyzing a sample of industrial firm data from 1970 through 1989, Lang et al. (1996) finds a strong negative relation between changes in leverage and future capital expenditures for low q firms - firms that lack valuable investment opportunities known to outside investors. In a similar study $\mathrm{Hu}$ (1999) finds a strong negative relationship between the lagged change in leverage and current capital expenditures. One explanation is that the adverse impact of leverage restricts managers of firms with poor investment opportunities from investing when they should not. We argue that there is an inflection point, after which, as companies become more leveraged, the cost of debt will increase - for example, because of increased bankruptcy risk - and negatively impact the weighted average cost of capital and a firm's available pool of positive NPV projects. Myers (1977) shows that a firm's debt overhang can be large enough to prevent it from raising additional funds to finance NPV positive projects. Analyzing nonfinancial and nonutility firm data from 1975 through 2002, Cai and Zhang (2011) show a significant and negative effect of the change in a firm's leverage ratio on that firm's capital expenditures. Several other studies (e.g., Lang et al., 1996; Marchica and Mura, 2010; Dang, 2011) have shown that (beginning) leverage is negatively associated with future capital expenditures. Kahle and Stulz (2013) question that causal link between corporate borrowing and capital expenditures with their findings that during the 20082009 financial crisis bank-dependent firms did not decrease their capital expenditures any more than their non-bank-dependent counterparts while unlevered firms decreased their capital expenditures more than highly levered firms. However, unlevered firms may be prevented from having access to debt and thus decreased their capital expenditures - even more than the highly-levered firms in their sample. Consistent with prior findings in the literature, we expect that - as firms become more highly levered - the cost of debt eventually approaches the cost of equity capital, at which points the firm's pool of available positive NPV projects is in decline. Thus, we argue that there is an inflection point after which a change in leverage increases a firm's weighted average cost of capital and, in turn, decreases that firm's capital expenditures. This leads to our fourth hypothesis:

H4: For highly leveraged firms, a change in leverage is negatively associated with a change in the concurrent capital expenditures. 
We now turn to a description of our sample and the variables used in this study.

\section{DATA AND METHODOLOGY}

We obtain financial statement data from annual Compustat files for the sample period 2000-2019. We exclude financial firms (standard industrial classification [SIC] codes 6000-6999) and utility firms' (SIC codes 4900-4999) since these firms are heavily regulated. We also require that firms have at least five million in sales and total assets. Our matched sample contains 17,466 firm years of the total 74,906 firmyear observations thus obtained. We further winsorize all continuous variables at the 1st and 99th percentiles to address any potential outlier problems. Table 2 presents summary statistics for the matched sample.

TABLE 2

SUMMARY STATISTICS

\begin{tabular}{|c|c|c|c|c|c|c|}
\hline \multicolumn{4}{|c|}{$\begin{array}{l}\text { Panel A: Descriptive Statistics } \\
\text { This panel presents the summary statistics of variables used in our analyses. All variables are defined in } \\
\text { the appendix. }\end{array}$} & & & \\
\hline \multicolumn{7}{|c|}{$\begin{array}{lllllll}\text { Variable } & \text { N } & \text { Mean } & \text { Std Dev } & \text { P25 } & \text { Median } & \text { P75 }\end{array}$} \\
\hline \multicolumn{7}{|l|}{ ch capx } \\
\hline lev_buyback & 17,466 & 0.50 & 0.50 & 0.00 & 0.50 & 1.00 \\
\hline high_lev_lummy & 17,466 & 0.52 & 0.50 & 0.00 & 1.00 & 1.00 \\
\hline \multirow{2}{*}{$\begin{array}{l}\text { lag_roa } \\
\text { lag_log_at }\end{array}$} & 17,466 & -0.55 & 0.31 & -0.61 & -0.46 & -0.34 \\
\hline & 17,466 & 7.00 & 2.05 & 5.57 & 7.02 & 8.39 \\
\hline \multirow{2}{*}{$\begin{array}{l}\text { lag_mtb } \\
\text { lag_z_score }\end{array}$} & 17,466 & 1.59 & 1.24 & 0.83 & 1.21 & 1.88 \\
\hline & 17,466 & 4.03 & 4.65 & 1.90 & 3.12 & 4.87 \\
\hline \multirow{2}{*}{$\begin{array}{l}\text { lag_cash } \\
\text { lag_cfo }\end{array}$} & 17,466 & 0.15 & 0.16 & 0.03 & 0.09 & 0.20 \\
\hline & 17,466 & 0.12 & 0.11 & 0.08 & 0.12 & 0.17 \\
\hline
\end{tabular}

Panel B: Matching based on industry, year, total assets, and lag capital expenditures This panel presents the summary statistics of variables by group. The first group (lev_buyback $=0$ ) include firms that did not use debt for repurchase and the second group (lev_buyback $=1$ ) includes firms that repurchased using debt and the second group include firms that did not use debt for repurchase.

\begin{tabular}{|c|c|c|c|c|c|}
\hline lev_buyback & $\begin{array}{l}\text { Control } \\
\text { Sample (0) }\end{array}$ & $\begin{array}{l}\text { Treatment } \\
\text { sample (1) }\end{array}$ & & & \\
\hline & Mean & & $\begin{array}{l}\text { Differences in } \\
\text { Mean }\end{array}$ & t-value & p-value \\
\hline total assets & 7523 & 7766 & -243 & -0.71 & 0.48 \\
\hline lag_capx & 5.5 & 5.4 & 0.1 & 0.69 & 0.49 \\
\hline Number of observations & 8,733 & 8,733 & & & \\
\hline
\end{tabular}


Panel C: Descriptive Statistics by groups

This panel presents the summary statistics of variables by groups. The first group (lev_buyback=0) include firms that did not use debt for repurchase and the second group (lev_buyback=1) includes firms that repurchased using debt and the second group include firms that did not use debt for repurchase.

\begin{tabular}{lllllllllll}
\hline Variable & Mean & \multicolumn{4}{c}{ Std Dev } & \multicolumn{1}{l}{ P25 } & \multicolumn{3}{c}{ Median } & P75 \\
lev_buyback & $\mathbf{0}$ & $\mathbf{1}$ & $\mathbf{0}$ & $\mathbf{1}$ & $\mathbf{0}$ & $\mathbf{1}$ & $\mathbf{0}$ & $\mathbf{1}$ & $\mathbf{0}$ & $\mathbf{1}$ \\
ch_capx & $\mathbf{- 0 . 0 2}$ & $\mathbf{1 . 2 0}$ & $\mathbf{3 . 9 4}$ & $\mathbf{5 . 0 9}$ & $\mathbf{- 0 . 9 2}$ & $\mathbf{- 0 . 4 1}$ & $\mathbf{0 . 0 2}$ & $\mathbf{0 . 3 2}$ & $\mathbf{0 . 9 3}$ & $\mathbf{1 . 5 9}$ \\
high_lev_dummy & $\mathbf{0 . 4 8}$ & $\mathbf{0 . 5 5}$ & $\mathbf{0 . 5 0}$ & $\mathbf{0 . 5 0}$ & $\mathbf{0 . 0 0}$ & $\mathbf{0 . 0 0}$ & $\mathbf{0 . 0 0}$ & $\mathbf{1 . 0 0}$ & $\mathbf{1 . 0 0}$ & $\mathbf{1 . 0 0}$ \\
lag_roa & $\mathbf{- 0 . 5 5}$ & $\mathbf{- 0 . 5 4}$ & $\mathbf{0 . 3 1}$ & $\mathbf{0 . 3 1}$ & $\mathbf{- 0 . 5 5}$ & $\mathbf{- 0 . 6 1}$ & $\mathbf{- 0 . 4 6}$ & $\mathbf{- 0 . 4 6}$ & $\mathbf{- 0 . 3 4}$ & $\mathbf{- 0 . 3 4}$ \\
lag_log_at & $\mathbf{6 . 9 1}$ & $\mathbf{7 . 1 0}$ & $\mathbf{2 . 1 0}$ & $\mathbf{1 . 9 9}$ & $\mathbf{5 . 3 9}$ & $\mathbf{5 . 7 8}$ & $\mathbf{6 . 8 4}$ & $\mathbf{7 . 1 6}$ & $\mathbf{8 . 3 4}$ & $\mathbf{8 . 4 4}$ \\
lag_mtb & $\mathbf{1 . 6 7}$ & $\mathbf{1 . 5 0}$ & $\mathbf{1 . 3 6}$ & $\mathbf{1 . 1 2}$ & $\mathbf{0 . 8 4}$ & $\mathbf{0 . 8 2}$ & $\mathbf{1 . 2 5}$ & $\mathbf{1 . 1 8}$ & $\mathbf{2 . 0 0}$ & $\mathbf{1 . 7 8}$ \\
lag_z_score & $\mathbf{4 . 6 1}$ & $\mathbf{3 . 4 5}$ & $\mathbf{5 . 2 7}$ & $\mathbf{3 . 8 5}$ & $\mathbf{2 . 0 4}$ & $\mathbf{1 . 7 6}$ & $\mathbf{3 . 4 1}$ & $\mathbf{2 . 9 0}$ & $\mathbf{5 . 5 8}$ & $\mathbf{4 . 3 2}$ \\
lag_cash & $\mathbf{0 . 1 7}$ & $\mathbf{0 . 1 2}$ & $\mathbf{0 . 1 8}$ & $\mathbf{0 . 1 4}$ & $\mathbf{0 . 0 4}$ & $\mathbf{0 . 0 3}$ & $\mathbf{0 . 1 1}$ & $\mathbf{0 . 0 7}$ & $\mathbf{0 . 2 5}$ & $\mathbf{0 . 1 6}$ \\
lag_cfo & $\mathbf{0 . 1 3}$ & $\mathbf{0 . 1 2}$ & $\mathbf{0 . 1 1}$ & $\mathbf{0 . 1 0}$ & $\mathbf{0 . 0 8}$ & $\mathbf{0 . 0 8}$ & $\mathbf{0 . 1 3}$ & $\mathbf{0 . 1 2}$ & $\mathbf{0 . 1 8}$ & $\mathbf{0 . 1 7}$ \\
\hline \hline
\end{tabular}

Panel A of Table 2 presents the descriptive statistics of the matched sample. The average change in capital expenditures is $.59 \%$, and the median change in capital expenditures is $0.17 \%$. By construction, $50 \%$ of firms use debt to repurchase stock, and the remaining 50\% do not use debt, i.e., these control firms may use internally generated cash or generate cash using equity, or both. We refer to the latter group as cashfinanced repurchase firm years. A Z-score of four suggests that firms, on average, are financially healthy and do not face bankruptcy risk in the near future. Finally, firms on average hold about $15 \%$ of their total assets in cash and short-term investments.

We use the propensity score matching (PSM) approach to match debt-financed repurchase firm years (lev buyback $=1$ ) and cash-financed repurchase firm years (lev buyback $=0)$ in order to test our first hypothesis. A propensity score is the probability of a unit being treated with the intervention of interest, given a set of observed explanatory variables.

Propensity scores are used to reduce selection bias by matching groups based on observed explanatory variables. There are limitations to using propensity scores as they can only match across observed covariates so that the results may still be influenced by unobserved/unmeasured characteristics. The idea is to match a treatment group to a control group with similar characteristics. Similar to BC (2018), we match samples based on the greedy nearest neighbor matching approach without replacement. This approach attempts to match an individual control firm to an individual treatment firm closest in terms of the propensity score. In this case, an individual debt-financed repurchase firm year from a given industry is matched to a cashfinanced repurchase firm year with a similar level of total assets and capital expenditures in the previous year within the same industry to control for any cross-sectional influence on capital expenditures. Specifically, we match samples on the following dimensions:

Treatment Group $=f$ (Total assets, Lag capital expenditures, Industry- and Year-Fixed Effects)

Panel B of Table 2 reports the mean and difference in means between our matched sample by treatment and control group; that is, debt-financed repurchase firm years $\left(\mathrm{lev}_{-}\right.$buyback $\left.=1\right)$ and cash-financed repurchase firm years $($ lev_buyback $=0)$, respectively. The mean total assets of cash-financed repurchase firm years (lev_buyback $=0$ ) is 7,523 million whereas that of debt-financed repurchase firm years (lev buyback $=1$ ) is 7,766. The difference in means (243) is neither economically nor statistically significant. The result is similar for the difference in means of lag_capx between the two groups. The results in Panel B give us assurance that the two groups are well matched across years, industry, total assets, and lag_capx.

Panel $\mathrm{C}$ of Table 2 presents the descriptive statistics of the treatment and the control sample across all the control variables used in the regression. Of particular interest is the difference in the change in capital expenditures between these two groups. The debt-financed repurchase firms invest $1.2 \%$ more in capital 
expenditures in the current year compared to the previous year, whereas the cash-financed repurchase firms invest $.02 \%$ less in the current year compared to the previous year. This evidence is consistent with our hypothesis that debt-financed repurchase firms invest more in concurrent capital expenditures than cashfinanced repurchase firms.

Table 3 presents the correlation between the variables used in our regressions. Consistent with $\mathrm{H} 1$, the change in capital expenditures is positively (.13) related to lev_buyback. Consistent with $\mathrm{H} 2$, the change in capital expenditures is positively (.20) related to the change in leverage. Finally, consistent with H3, the correlation between the change in capital expenditures and the high_lev_dummy is negative (-.04) and significant, suggesting that highly leveraged firms invest less in capital expenditures in the current year as compared to the previous year. More importantly, it suggests a potential moderating effect of the level of leverage in the relation between change in capital expenditures and lev_buyback; that is, the relation between change in capital expenditures and lev_buyback depends on the level of leverage.

\section{TABLE 3 \\ CORRELATION MATRIX}

\begin{tabular}{lllllllllll}
\hline & & \multicolumn{1}{c}{ Pearson Correlation Coefficients, $\mathbf{N}=\mathbf{1 7 , 4 6 6}$} \\
& & $\mathbf{1}$ & $\mathbf{2}$ & $\mathbf{3}$ & $\mathbf{4}$ & $\mathbf{5}$ & $\mathbf{6}$ & $\mathbf{7}$ & $\mathbf{8}$ & $\mathbf{9}$ \\
1 & ch_capx & & & & & & & & & \\
2 & lev_buyback & $\mathbf{0 . 1 3}$ & & & & & & & & \\
3 & high_lev_dummy & $\mathbf{- 0 . 0 4}$ & $\mathbf{0 . 0 7}$ & & & & & & & \\
4 & lag_roa & $\mathbf{0 . 0 8}$ & $\mathbf{- 0 . 0 3}$ & $\mathbf{- 0 . 0 3}$ & & & & & & \\
5 & lag_log_at & $\mathbf{- 0 . 0 5}$ & $\mathbf{0 . 0 5}$ & $\mathbf{0 . 2 3}$ & $\mathbf{0 . 2 1}$ & & & & & \\
6 & lag_mtb & $\mathbf{0 . 0 9}$ & $\mathbf{- 0 . 0 7}$ & $\mathbf{- 0 . 0 8}$ & $\mathbf{0 . 2 0}$ & $\mathbf{- 0 . 0 3}$ & & & & \\
7 & lag_z_score & $\mathbf{0 . 0 8}$ & $\mathbf{- 0 . 1 2}$ & $\mathbf{- 0 . 2 9}$ & $\mathbf{0 . 3 1}$ & $\mathbf{- 0 . 1 3}$ & $\mathbf{0 . 6 2}$ & & & \\
8 & lag_cash & $\mathbf{0 . 0 4}$ & $\mathbf{- 0 . 1 6}$ & $\mathbf{- 0 . 2 7}$ & $\mathbf{- 0 . 1 0}$ & $\mathbf{- 0 . 2 3}$ & $\mathbf{0 . 3 5}$ & $\mathbf{0 . 3 6}$ & & \\
9 & lag_cfo & $\mathbf{0 . 0 8}$ & $\mathbf{- 0 . 0 4}$ & $\mathbf{0 . 0 2}$ & 0.61 & $\mathbf{0 . 1 5}$ & 0.11 & $\mathbf{0 . 1 7}$ & $\mathbf{- 0 . 2 2}$ & \\
10 & ch_lev & $\mathbf{0 . 2 0}$ & $\mathbf{0 . 5 1}$ & $\mathbf{- 0 . 0 5}$ & $\mathbf{0 . 0 4}$ & $\mathbf{- 0 . 0 4}$ & $\mathbf{0 . 1 1}$ & $\mathbf{0 . 0 4}$ & 0.00 & $\mathbf{0 . 0 2}$ \\
\hline \hline
\end{tabular}

This table presents the Pearson correlation of variables used in our analyses. Bold values indicate that the correlation coefficient is significantly different from zero at the $\mathrm{p}<0.05$ level (two-tailed). All variables are defined in the appendix.

\section{RESULTS AND DISCUSSION}

Columns 1 and 2 of Table 4 present the results for H1; i.e., whether debt-financed repurchasing firms and their cash-financed repurchasing counterparts exhibit similar capital expenditures behavior. In Column 1 , the dependent variable is the change in capital expenditures and the independent variable of interest is lev_buyback. The sign on the coefficient for lev_buyback is positive (1.391) and statistically significant at the $1 \%$ level. Using the point estimate in Column 1 to gauge the economic effect of lev_buyback, we find that a debt-financed repurchase firms is associated with a $1.391 \%$ percentage point increase in capital expenditures. On a dollar basis, this means that the debt-financed repurchase firms increase their capital expenditures by $\$ 5.3$ million more than the cash-financed repurchase firms. Thus, the funding source used to repurchase shares not only has statistical significance but also holds meaningful economic importance. Cash is positively associated with capital expenditures (Lei and Zhang 2016). Also, profitable firms proxied by ROA and firms with higher cash flow from operations invest more in capital expenditures. Finally, firms with higher growth opportunities as proxied by the market-to-book ratio invest more in capital expenditures (Jagannathan et al. 2000, Lei and Zhang 2016). In Column 2, we control for industry and year fixed effects and get similar results. Overall, we find that firms using debt to repurchase shares increase their capital expenditures more than their peers who use cash to repurchase shares. 
Columns 3 and 4 of Table 4 present the results for H2. We include the lev_buyback_highlev_dum -a dummy variable capturing the interaction between lev_buyback and high_lev_dummy - to test whether the relation between lev_buyback and the change in capital expenditures depends on the current level of leverage of the firm. If a firm has a relatively low level of leverage, it may be able to borrow at an interest rate that effectively lowers the weighted average cost of capital, increasing that firm's pool of NPV positive projects. However, if the firm is already highly leveraged, then it may not be able to secure a loan at an interest rate that sufficiently lowers the weighted average cost of capital. So, if a highly leveraged firm can secure debt to repurchase shares, they may potentially invest less in capital expenditures than a lessleveraged peer. We find results consistent with this hypothesis. The coefficients on the interaction term lev_buyback_highlev_dum are negative (-0.366 in column 3 and -0.385 in column 4$)$ and significant at a $1 \%$ level across both specifications.

TABLE 4

LEVERAGED SHARE REPURCHASES AND CHANGE IN CAPX

\begin{tabular}{|c|c|c|c|c|}
\hline \multirow{2}{*}{$\begin{array}{l}\text { Dependent variable } \\
\text { Variable }\end{array}$} & \multicolumn{4}{|c|}{ Change in Capital expenditures } \\
\hline & 1 & 2 & 3 & 4 \\
\hline Intercept & -0.029 & $-0.817 *$ & -0.125 & $-0.925 * *$ \\
\hline & $(-0.16)$ & $(-1.85)$ & $(-0.68)$ & $(-2.09)$ \\
\hline lev_buyback & $\begin{array}{l}1.391 * * * \\
(17.31)\end{array}$ & $\begin{array}{l}1.375 * * * \\
(17.52)\end{array}$ & $\begin{array}{l}1.585 * * * \\
(13.12)\end{array}$ & $\begin{array}{l}1.578 * * * \\
(13.45)\end{array}$ \\
\hline high_lev_dummy & $-0.136 *$ & -0.022 & 0.056 & $0.180 *$ \\
\hline & $(-1.78)$ & $(-0.30)$ & $(0.58)$ & $(\mathbf{1 . 8 5})$ \\
\hline levbuyback_highlev_dum & & & $\begin{array}{l}-0.366 * * \\
(-2.53)\end{array}$ & $\begin{array}{l}-0.385 * * * \\
(-2.69)\end{array}$ \\
\hline lag_roa & $\begin{array}{l}1.737 * * * \\
(3.27)\end{array}$ & $\begin{array}{l}2.388 * * * \\
(4.50)\end{array}$ & $\begin{array}{l}1.759 * * * \\
(3.32)\end{array}$ & $\begin{array}{l}2.411 * * * \\
(4.55)\end{array}$ \\
\hline lag_log_at & $\begin{array}{l}-0.136 * * * \\
(-6.68)\end{array}$ & $\begin{array}{l}-0.149 * * * \\
(-7.09)\end{array}$ & $\begin{array}{l}-0.138^{* * * *} \\
(-6.75)\end{array}$ & $\begin{array}{l}-0.151 * * * \\
(-7.16)\end{array}$ \\
\hline lag_mtb & $\begin{array}{l}0.215 * * * \\
(4.92)\end{array}$ & $\begin{array}{l}0.265 * * * \\
(5.53)\end{array}$ & $\begin{array}{l}0.213 * * * \\
(4.87)\end{array}$ & $\begin{array}{l}0.262 * * * \\
(5.48)\end{array}$ \\
\hline lag_z_score & $\begin{array}{l}0.011 \\
(0.66)\end{array}$ & $\begin{array}{l}0.019 \\
(1.11)\end{array}$ & $\begin{array}{l}0.012 \\
(0.74)\end{array}$ & $\begin{array}{l}0.020 \\
(1.20)\end{array}$ \\
\hline lag_cash & $\begin{array}{l}\text { 1.016*** } \\
(3.81)\end{array}$ & $\begin{array}{l}1.657 * * * \\
(5.96)\end{array}$ & $\begin{array}{l}1.069 * * * \\
(4.00)\end{array}$ & $\begin{array}{l}1.709 * * * \\
(6.13)\end{array}$ \\
\hline lag_cfo & $\begin{array}{l}2.867 * * * \\
(4.63)\end{array}$ & $\begin{array}{l}1.270^{* * *} \\
(2.16)\end{array}$ & $\begin{array}{l}2.869 * * * \\
(4.64)\end{array}$ & $\begin{array}{l}1.271 * * \\
(2.16)\end{array}$ \\
\hline Observations & 17,466 & 17,466 & 17,466 & 17,466 \\
\hline R-squared & 0.040 & 0.090 & 0.040 & 0.090 \\
\hline Industry FE & No & Yes & No & Yes \\
\hline Year FE & No & Yes & No & Yes \\
\hline
\end{tabular}

This table presents regression results with change in capital expenditures (ch_capx) as the dependent variable. Ch_capx equals annual change in capital expenditures (Compustat data item 128) divided by beginning total assets (Compustat data item 6) multiplied by 100. Lev_buyback is a dummy variable that takes the value 1 if a firm has repurchased shares (Compustat data item 115) and the long-term debt (Compustat data item 9) changes by more than $50 \%$ of share repurchase amount during the year, and 0 otherwise. High_lev_dummy that takes the value 1 if a firm has long-term debt/total assets ratio of higher than median within a given industry during the year, and 0 otherwise. Levbuyback_highlev_dum is an interaction variable between lev_buyback and high_lev_dummy. T-statistics based on heteroscedasticity-robust standard errors clustered by firms are reported in parentheses. Variables are defined in the appendix. All continuous variables are winsorized at the $1 \%$ and $99 \%$ percentiles. The significance levels at the $1 \%, 5 \%$, and $10 \%$ are indicated with $* * *, * *$, and $*$, respectively. 
Our central argument is that the cost of debt, on average, is lower than the cost of equity. Hence, repurchasing shares with debt lowers the weighted average cost of capital, enabling companies to undertake projects they otherwise may not have considered. As argued above, an increase in leverage decreases the weighted average cost of capital, which increases the pool of NPV positive projects to the firm. For our argument to hold, there must be a positive association between the change in leverage and the change in capital expenditures. This section provides direct evidence of the association between change in leverage and concurrent change in capital expenditures.

TABLE 5

CHANGE IN LEVERAGE AND CHANGE IN CAPITAL EXPENDITURES

\begin{tabular}{|c|c|c|c|c|c|c|}
\hline \multirow{3}{*}{$\begin{array}{l}\text { Dependent variable } \\
\text { Variable } \\
\text { Intercept }\end{array}$} & \multicolumn{6}{|c|}{ Change in Capital expenditures } \\
\hline & 1 & 2 & 3 & 4 & 5 & 6 \\
\hline & $0.411 * * *$ & $(\mathbf{0 . 5 3})$ & $0.525 * * *$ & -0.380 & $0.352 * * *$ & $(0.59)$ \\
\hline & $(5.71)$ & $(-0.83)$ & $(6.75)$ & $(-0.67)$ & $(4.81)$ & $(-0.95)$ \\
\hline \multirow[t]{2}{*}{ ch_lev } & $0.075 * * *$ & $0.071 * * *$ & & & $0.087 * * *$ & $0.083 * * *$ \\
\hline & $(25.43)$ & $(25.21)$ & & & (18.27) & (18.15) \\
\hline \multirow[t]{2}{*}{ high_lev_dummy } & & & $-0.294 * * *$ & $-0.136 * * *$ & 0.058 & $0.183 * * *$ \\
\hline & & & $(-6.18)$ & $(-2.94)$ & (1.30) & $(4.14)$ \\
\hline \multirow[t]{2}{*}{ chlev_highlev_dum } & & & & & $-0.021 * * *$ & $-0.019 * * *$ \\
\hline & & & & & $(-3.66)$ & $(-3.55)$ \\
\hline \multirow[t]{2}{*}{ lag_roa } & $1.898 * * *$ & $1.971 * * *$ & $2.106 * * *$ & $2.110 * * *$ & $1.943 * * *$ & $2.008 * * *$ \\
\hline & (11.39) & $(\mathbf{1 1 . 7 1 )}$ & $(12.54)$ & $(12.36)$ & (11.67) & (11.93) \\
\hline \multirow[t]{2}{*}{ lag_log_at } & $-0.147 * * *$ & $-0.149 * * *$ & $-0.123 * * *$ & $-0.143 * * *$ & $-0.145 * * *$ & $-0.157 * * *$ \\
\hline & $(-15.36)$ & $(-14.93)$ & $(-12.65)$ & $(-13.37)$ & $(-15.00)$ & $(-15.08)$ \\
\hline \multirow[t]{2}{*}{ lag_mtb } & $0.366 * * *$ & $0.368 * * *$ & $0.465 * * *$ & $0.443 * * *$ & $0.363 * * *$ & $0.358 * * *$ \\
\hline & $(14.94)$ & (14.96) & (18.23) & (17.49) & $(14.56)$ & (14.37) \\
\hline \multirow[t]{2}{*}{ lag_z_score } & $0.010 *$ & $0.011 *$ & 0.002 & 0.008 & $0.011 *$ & $0.014 * *$ \\
\hline & (1.65) & (1.71) & $(0.23)$ & (1.28) & $(1.68)$ & $(2.20)$ \\
\hline \multirow[t]{2}{*}{ lag_cash } & $0.499 * * *$ & $1.293 * * *$ & $0.255^{*}$ & $1.152 * * *$ & $0.535 * * *$ & $1.410 * * *$ \\
\hline & $(4.04)$ & (10.16) & (1.94) & (8.57) & (4.18) & (10.61) \\
\hline \multirow[t]{2}{*}{ lag_cfo } & $2.129 * * *$ & $1.394 * * *$ & $1.960 * * *$ & $1.248 * * *$ & $2.125 * * *$ & $1.396 * * *$ \\
\hline & $(8.74)$ & (5.99) & (7.91) & $(5.26)$ & (8.74) & $(6.00)$ \\
\hline Observations & 74,906 & 74,906 & 74,906 & 74,906 & 74,906 & 74,906 \\
\hline R-squared & 0.06 & 0.11 & 0.03 & 0.07 & 0.07 & 0.11 \\
\hline Industry FE & No & Yes & No & Yes & No & Yes \\
\hline Year FE & No & Yes & No & Yes & No & Yes \\
\hline
\end{tabular}

This table presents regression results with change in capital expenditures (ch capx) as the dependent variable. Ch_capx equals annual change in capital expenditures (Compustat data item 128$)$ divided by beginning total assets (Compustat data item 6) multiplied by 100. Ch_lev equals annual change in long term debt (Compustat data item 9) divided by beginning total assets (Compustat data item 6) multiplied by 100. High_lev_dummy takes the value 1 if a firm has long-term debt/total assets ratio of higher than median within a given industry during the year, and 0 otherwise. chlev_highlev_dum is an interaction variable between ch_lev and high_lev_dummy. T-statistics based on heteroscedasticity-robust standard errors clustered by firms are reported in parentheses. Variables are defined in the appendix. All continuous variables are winsorized at the $1 \%$ and $99 \%$ levels. The significance levels at the $1 \%, 5 \%$, and $10 \%$ are indicated with $* * *, * *$, and $*$, respectively. 
Table 5 presents the results for $\mathrm{H} 3$ and $\mathrm{H} 4$. In Column 1, the sign on the coefficient on ch_lev is positive $(0.075)$ and statistically significant at the $1 \%$ level. The positive association between the change in leverage and the change in capital expenditures holds even after including industry and year fixed effects in Column 2, providing support to our H3. In Columns 3 and 4, the sign on the coefficient on high_lev_dummy is negative (-0.294 and -0.136) and statistically significant at the $1 \%$ level, which suggests that highly leveraged firms make fewer capital investments than their less-leveraged peers. The results in Columns 3 and 4 underscore our point that companies will invest in capital expenditures if they get cheaper loans; however, if they are already highly leveraged then cheaper loans are not available so such firms will invest less in capital expenditures as compared to their peers.

In Columns 5 and 6, the sign on the coefficient for the chlev_highlev_dum variable is negative (-0.021 and -0.109 ) and statistically significant at the $1 \%$ level, which suggests that for highly leveraged firms, an increase in leverage is associated with a decrease in capital expenditures investments compared to less leveraged peers providing support to our H4. Overall, we provide evidence that a change in leverage is positively associated with a change in concurrent capital expenditures (Columns 1 and 2). However, if a firm is already highly leveraged, such a firm would invest less in capital expenditures than its peers (Columns 3 and 4). Finally, if a firm is highly leveraged and decides to increase their leverage even more, that firm would decrease its capital expenditures and use the borrowed funds and funds from shaving capital expenditures for some other purposes (Columns 5 and 6). 


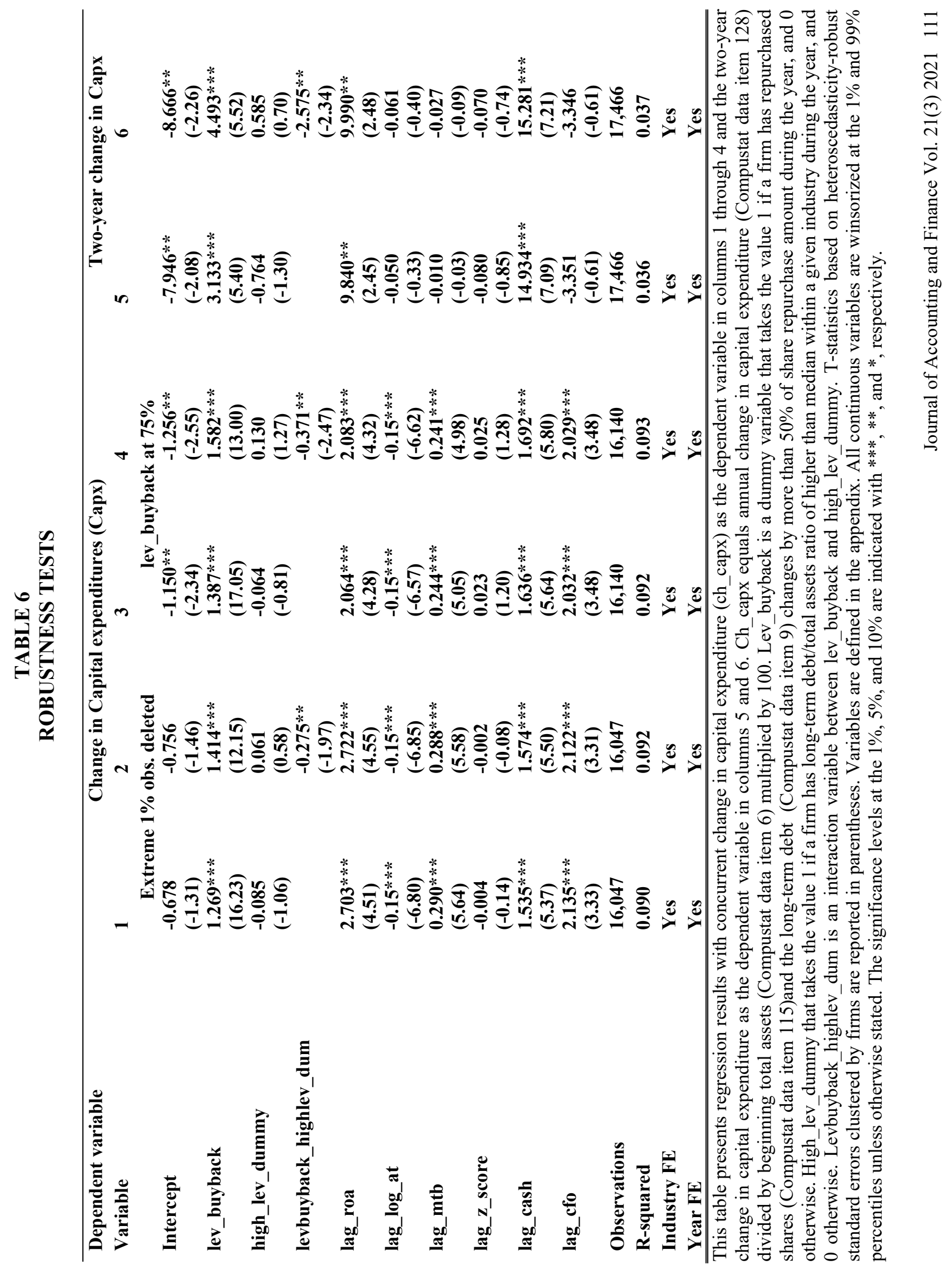


Table 6 presents results for our robustness tests. We observe in Table 2 that the average change in capital expenditures is $.59 \%$, and the median change in capital expenditures is $0.17 \%$. Since the median change in CAPX is significantly below the mean change, we begin our robustness tests by deleting (as opposed to winsorizing) the extreme one percent of all continuous variables to ensure that the outliers do not drive our results. Columns 1 and 2 of Table 6 presents our results with the extreme observations deleted. We find that our results continue to hold. We also change the definition of lev_buyback, where it is a dummy variable that takes the value 1 if a firm has repurchased shares and the long-term debt changes by more than $75 \%$ (as opposed to 50\%) of the share repurchase amount during the year, and 0 otherwise. The results for this exercise are presented in Columns 3 and 4 of Table 6 . We find that our results continue to hold.

One caveat of our study is that the choice of how to finance capital expenditures is endogenous and may be driven by factors that also influence the decision whether to repurchase shares. We attempt to address endogeneity concern and provide some evidence suggesting that the firms that finance their share repurchase lower their cost of capital not only to increase their capital expenditures concurrently but continue to spend more on capital expenditures in the following year. In Columns 5 and 6 of Table 6, we employ the two years change in capital expenditures as our dependent variable and continue to find that firms that borrow to finance their share repurchase spend more on capital expenditures over two years following the share repurchases and that the highly leveraged firms spend less on capital expenditures in those two years following the share repurchase as compared to the less-leveraged firms. Hence, Columns 5 and 6 provide evidence consistent with our argument that some firms are repurchasing shares to lower the weighted average cost of capital, allowing their managers to increase capital expenditures by providing access to a larger pool of positive NPV projects.

\section{CONCLUSION}

In this paper, we examine the relationship between the financing of share repurchases and concurrent capital expenditures. Using a matched sample of debt-financed and cash-financed repurchasing firms from 2000 through 2019, we find that debt-financed repurchasing firms spend more on concurrent capital expenditures than their cash-financed repurchasing counterparts. Consistent with prior literature, we find a negative relationship between the level of leverage and current capital expenditures. High-levered firms that take on more debt spend less on capital expenditures than comparable low-levered firms.

Because a debt-financed repurchase increases a firm's leverage more than a cash-financed repurchase, we expand our investigation to the relationship between the change in leverage and the change in concurrent capital expenditures. Again, we find a positive relationship between the two variables that is significant both economically and statistically. We attribute this finding to the effect of a change in leverage on the firm's cost of capital. Higher leverage decreases the cost of capital, which increases the firm's pool of available positive NPV projects and allows its managers to increase capital expenditures.

\section{REFERENCES}

Almeida, H., Fos, V., \& Kronlund, M. (2016). The real effects of share repurchases. Journal of Financial Economics, 119(1), 168-185.

BC, B. (2018). Bank lending and strategic R\&D disclosure. Banking and Finance Review, 10(2), 103-130.

BC, B., Bhagwat, Y.N., \& DeBruine, M. (2019). Do repurchasing firms shave capital expenditures when signaling? Academy of Accounting and Financial Studies Journal, 23(4), 1-11.

Bhagwat, Y.N., \& DeBruine, M. (2018). Do firms shave capital expenditures when repurchasing shares? Academy of Accounting and Financial Studies Journal, 22(6), 1-10.

Bonaimé, A.A., Öztekin, Ö., \& Warr, R.S. (2014). Capital structure, equity mispricing, and stock repurchases. Journal of Corporate Finance, 26, 182-200.

Blundell-Wignall, A., \& Roulet, C. (2013). Long-term investment, the cost of capital and the dividend and buyback puzzle. OECD Journal: Financial Market Trends, 2013(1), 39-52. 
Brav, A., Graham, J.R., Harvey, C.R., \& Michaely, R. (2005). Payout policy in the 21st century. Journal of Financial Economics, 77(3), 483-527.

Cai, J., \& Zhang, Z. (2011). Leverage change, debt overhang, and stock prices. Journal of Corporate Finance, 17(3), 391-402.

Dang, V.A. (2011). Leverage, debt maturity and firm investment: An empirical analysis. Journal of Business Finance \& Accounting, 38(1-2), 225-258.

Dittmar, A.K., \& Dittmar, R.F. (2008). The timing of financing decisions: An examination of the correlation in financing waves. Journal of Financial Economics, 90(1), 59-83.

Dittmar, A., \& Field, L.C. (2015). Can managers time the market? Evidence using repurchase price data. Journal of Financial Economics, 115(2), 261-282.

Fama, E.F., \& French, K.R. (2001). Disappearing dividends: Changing firm characteristics or lower propensity to pay? Journal of Financial Economics, 60(1), 3-43.

Floyd, E., Li, N., \& Skinner, D.J. (2015). Payout policy through the financial crisis: The growth of repurchases and the resilience of dividends. Journal of Financial Economics, 118(2), 299-316.

Grullon, G., \& Michaely, R. (2004). The information content of share repurchase programs. Journal of Finance, 59(2), 651-680.

Hribar, P., Jenkins, N.T., \& Johnson, W.B. (2006). Stock repurchases as an earnings management device. Journal of Accounting and Economics, 41(1-2), 3-27.

Ikenberry, D., Lakonishok, J., \& Vermaelen, T. (1995). Market under-reaction to open market share repurchases. Journal of Financial Economics, 39(2-3), 181-208.

Jagannathan, M., Stephens, C.P., \& Weisbach, M.S. (2000). Financial flexibility and the choice between dividends and stock repurchases. Journal of Financial Economics, 57(3), 355-384.

Jensen, M.C. (1986). Agency costs of free cash flow, corporate finance, and takeovers. The American Economic Review, 76(2), 323-329.

Kahle, K.M. (2002). When a buyback isn't a buyback: Open market repurchases and employee options. Journal of Financial Economics, 63, 235-261.

Kahle, K.M., \& Stulz, R.M. (2013). Access to capital, investment, and the financial crisis. Journal of Financial Economics, 110(2), 280-299.

Lang, L., Ofek, E., \& Stulz, R. (1996). Leverage, investment, and firm growth. Journal of Financial Economics, 40(1), 3-29.

Lazonick, W. (2014). Profits without prosperity. Harvard Business Review, 92(9), 46-55.

Lazonick, W., Sakinç, M.E., \& Hopkins, M. (2020). Why Stock Buybacks are Dangerous for the Economy. Harvard Business Review. Retrieved on June 12, 2020, from https://hbr.org/2020/01/why-stock-buybacks-are-dangerous-for-the-economy

Lei, Z., \& Zhang, C. (2016). Leveraged buybacks. Journal of Corporate Finance, 39, 242-262.

Lie, E. (2002). Do firms undertake self-tender offers to optimize capital structure? The Journal of Business, 75(4), 609-639.

Marchica, M.T., \& Mura, R. (2010). Financial flexibility, investment ability, and firm value: Evidence from firms with spare debt capacity. Financial Management, 39(4), 1339-1365.

Milano, G., \& Chew, M. (2019). Save the buyback, save jobs. Journal of Applied Corporate Finance, $31(1), 126-128$.

Myers, S. (1977). Determinants of corporate borrowing. Journal of Financial Economics, 5, 147-175.

Richardson, S. (2006). Over-investment of free cash flow. Review of Accounting Studies, 11(2-3), 159189.

Tsetsekos, G.P., Kaufman, D.J., \& Gitman, L.J. (1991). A survey of stock repurchase motivations and practices of major US corporations. Journal of Applied Business Research, 7(3), 15-21. 


\section{APPENDIX}

\author{
Variables \\ ch_capx \\ lev_buyback \\ high_lev_dummy \\ ch_lev \\ lag_roa \\ lag_log_at \\ lag_mtb
}

lag_z_score

lag1_lev

lag_cash

lag_cfo

Two-year change

in capx

\section{Description}

Annual change in capital expenditures (Compustat data item 128) divided by beginning total assets (Compustat data item 6) multiplied by 100 .

Dummy variable that takes the value 1 if a firm has repurchased shares (Compustat data item 115) and the long-term debt (Compustat data item 9) changes by more than $50 \%$ of share repurchase amount during the year, and 0 otherwise.

Dummy variable that takes the value 1 if a firm has long-term debt/total assets ratio of higher than median within a given industry during the year, and 0 otherwise.

Annual change in long term debt (Compustat data item 9) divided by beginning total assets (Compustat data item 6) multiplied by 100 .

Lagged value of Net Income/Loss (Compustat data item 172) divided by total assets (Compustat data item 6).

Lagged value of Log of total assets (Compustat data item 6).

Lagged value of Market to book (Market value of common stock + total debt + preferred stock - deferred taxes and investment tax credit) / Book Assets \{prcc_f $*$ cshpri $+\mathrm{dlc}+\mathrm{dltt}+$ pstkl-txditc/at $\}$.

Lagged value of Altman's (1968) Z-score computed as $Z=1.2$ (working capital/total assets) +1.4 (retained earnings/total assets) + 3.3 (EBIT/total assets) +0.6 (market value of equity/book value of total liabilities $)+($ sales/total assets $)\left\{1.2 *(\right.$ wcap $/$ at $)+1.4 *($ re $/$ at $)+3.3^{*}$ (ib/at) $+0.6^{*}(\mathrm{mve} / \mathrm{lt})+($ sale/at $\left.)\right\}$.

Lagged value of Long-term debt (Compustat data item 9) divided by total assets (Compustat data item 6).

Lagged value of Cash and Short-Term Investments (Compustat data item 1) divided by total assets (Compustat data item 6).

Lagged value of Cash flow from operations (Operating Income Before Depreciation-Interest and Related Expense-Cash Dividends-Income Taxes+Depreciation and Amortization) divided by total assets (Compustat data item 6) \{(oibdp-xint-dv-txt+dp)/at $\}$

$\left\{\left(\operatorname{capx}_{\mathrm{t}}+\operatorname{capx}_{\mathrm{t}+1}\right)-\left(\operatorname{capx}_{\mathrm{t}}+\operatorname{capx}_{\mathrm{t}-1}\right)\right\} / \mathrm{at}_{\mathrm{t}-1}$ 